\title{
Beyond financialisation? How direct regulation will transform the future of financial market structures
}

\author{
Dieter Pesendorfer*
}

School of Law, Queen's University Belfast

\section{Introduction}

$\mathrm{O}$ ver the last few years since the financial crash in 2008, it has become clear that the structure of financial markets is a major threat for financial stability and wealth, and this not just for countries as diverse as Austria (with its extensive exposure to Central and Southern Eastern European countries), Cyprus, Iceland, Sweden (with a banking crisis in the early 1990s), or the UK, where the financial sector has grown to a proportion of the gross domestic product that could only too easily bring down these economies entirely, not to mention the global effects that could occur in a worst case scenario. Throughout the most developed countries modern finance has become a too complex system with a huge variety of financial institutions which no longer only perform services of financial intermediation in terms of classical banking definitions. Massively driven by speculation, this system is characterised by a dominance of internationally active megabanks and large financial conglomerates; by complex national and transnational interconnections between banks as well as between banks and the 'shadow banking' world; by excessive leverage; and by a lack of transparency especially with regard to these opaque structures and the underlying products and activities that reproduce them. The global financial crisis itself, as well as numerous scandals, such as the 2010 Flash Crash, the spectacular JPMorgan's 'London whale trade losses' in 2012, or the Libor manipulations, illustrated to the public that this system and its risks cannot be managed adequately and that regulatory oversight remains a mission impossible. Although most megabanks have returned to large profits and so-called systemically important financial institutions (SIFIs) have passed official stress tests for which they had to increase capital buffers, problematic pre-crisis trends have continued and partly even intensified. With a New York Times bestseller book title describing the situation at the time of the crash, one could argue that 'all the devils' ${ }^{1}$ are still around or side with Admati and Hellwig that 'even with proposed reforms' the emerging system 'is as dangerous and fragile as the system that brought us the recent crisis'. ${ }^{2}$ Moreover, the toobig-to-fail (TBTF) institutions still profit in various ways from implicit government

\footnotetext{
d.pesendorfer@qub.ac.uk.

1 B McLean and J Nocera, All the Devils Are Here: Unmasking the Men Who Bankrupted the World (Portfolio/Penguin Press 2010).

2 A Admati and M Hellwig, The Bankers' New Clothes: What's Wrong with Banking and What to Do about It (Princeton UP 2013) xii.
} 
subsidies which are no longer seen as justifiable within an economic paradigm based on the idea of the superiority of highly competitive markets.

Emerging parallel with the overcomplex structures a cultural change in banking happened over recent decades that economists such as Paul Krugman or John Kay described as one from 'boring banking' of the 1950s and 1960s to a highly dynamic, innovative and fast-growing banking system, finally culminating in an excitement in this sector only comparable to the situation before the Wall Street Crash in 1929. ${ }^{3}$ The result is an emerging literature and political debate on the causes and effects of structures, cultures, incentives, products and activities. Many have analysed modern finance as 'casino banking' driven by recklessness, greed, corruption, and gambling, ${ }^{4}$ by 'mad money', 5 'madness with method', 6 or 'medieval alchemy' ${ }^{7}$ which undermines the 'real economy' and increases overall inequality and instability. This system, labelled by critics as 'casino capitalism', 8 "financialization' and a 'finance-led accumulation regime', 10 has produced numerous national and regional crises since its emergence in the 1970s, before finally proving how unstable, risky, destructive and costly it has become globally. However, before the global financial crisis, mainstream actors were convinced that modern finance had become safer thanks to deregulation, liberalisation, 'light-touch' regulation, business self-regulation and sophisticated risk management practices, such as diversification via securitisation. Stricter monetary policy, the trend towards independent central banks, and further policies described by critics as neoliberal were seen as major improvements that had led to a 'Great Moderation' with less macro-economic volatility allowing more leverage and high liquidity. ${ }^{11}$ Emerging markets and poor countries were seen as remaining sources for future financial crises and reform proposals focused on measures that would make their regulatory systems similar to those in the most developed countries. ${ }^{12}$

Now with the continuing global financial crisis in its various stages and multiple facets, its aftershocks and the return of 'crisis economics'13 with all kind of uncertainties and pressures to reform the very role of modern finance, its contemporary size, shape and dynamics are radically put into question. Proponents of the shareholder value paradigm propose radical reforms to rescue this idea from its distortions caused by short-termism. ${ }^{14}$ Economists as an entire discipline have started to explain how it came to the enormous

3 P Krugman, 'Making Banking Boring', New York Times (New York, 10 April 2009); P Krugman, 'Good and Boring', New York Times (New York 1 February 2010); J Kay, Narrow Banking: The Reform of Banking Regulation (2009) <www.johnkay.com/wp-content/uploads/2009/12/JK-Narrow-Banking.pdf>.

4 G Morgenson and J Rosner, Reckless Endangerment: How Outsized Ambition, Greed, and Corruption Led to Economic Armageddon (Times Books 2011).

5 S Strange, Mad Money: When Markets Outgrow Governments (University of Michigan Press 1998).

6 S Wagenknecht, Wahnsinn mit Methode: Finanzcrash und Weltwirtschaft (Das Neue Berlin 2009).

7 K Dowd and M Hutchinson, The Alchemists of Loss: How Modern Finance and Government Intervention Crashed the Financial System (John Wiley \& Sons 2010); A Nesvetailova, Financial Alchemy in Crisis (Pluto Press 2010).

8 S Strange, Casino Capitalism (Blackwell 1986).

9 G A Epstein (ed), Financialization and the World Economy (Edward Elgar Publishing 2005); G Krippner, What is Financialization? (mimeo, Department of Sociology, UCLA 2004).

10 M Aglietta, 'Capitalism at the Turn of the Century: Regulation Theory and the Challenge of Social Change' [1998] (Nov/Dec) NLR 41.

11 B S Bernanke, The Great Moderation (remarks by Governor Ben S Bernanke at the meetings of the Eastern Economic Association, Washington, DC, 20 February 2004) (Federal Reserve Board 2004) <www.federalreserve.gov/boarddocs/speeches/2004/20040220/default.htm>.

12 B Eichengreen, Financial Crises and What to Do About Them (OUP 2002).

13 N Roubini and S Mihm, Crisis Economics: A Crash Course in the Future of Finance (Allen Lane 2010).

14 A Rappaport, Saving Capitalism from Short-Termism: How to Build Long-Term Value and Take Back Our Financial Future (McGraw-Hill 2011). 
'misunderstanding' of financial crises ${ }^{15}$ but still struggle to understand what lessons to be drawn. ${ }^{16}$ System transformation with deleveraging and many other measures affecting the future structures of finance came on the agenda. Asking about the benefits of the size, structure and functions of finance and demanding quite radical change, as well as thinking about the optimum number and size of banks, about ways to decrease interconnectedness among firms and to improve competition, and about the overall future structures of finance have become not just popular among many regulators and law-makers but a key policy goal already resulting in numerous regulatory changes and proposals.

This paper analyses the various reforms and proposals and argues that in the area of structural reforms reformulations still remain within the overall system of financialisation. The adopted reforms include a number of significant loopholes and flaws that altogether lead to a result in which the overall dominance of finance will persist and create continued financial instability. By making regulatory proposals overly complex, loopholes and flaws were increased. Additionally, institutional arrangements remain problematic. Significant problems and uncertainties with regard to overly complex and opaque banking structures remain. However, the overall direction of reforms might still change in key jurisdictions and heavy aftershocks might quickly bring more radical, yet marginalised, proposals on the agenda. At least in theory one could assume that several reforms potentially lead to a more significant change via gradual institutional reforms, while more radical reforms would require much more political pressure and will. The next section will discuss why and how structure matters and why financial structures became a problem that needs to be resolved. Section 3 will look at various regulatory reforms and proposals addressing financial structures with a focus on measures that affect financial institutions directly, such as most prominently the Volcker Rule and ring-fencing. The concluding section will problematise the regulatory space for taming finance in times of crisis, austerity and increased public protest potential. It will be concluded that new regulatory strategies are required that draw the lessons from the failed radical reform proposals so far.

\section{Structures of finance matter}

Half a decade after the meltdown, regulators in a still highly politicised policy area are facing great expectations and public pressure to address the structural flaws of the current financial system and to make the future structures more robust and resilient. Before the crisis regulating finance was basically a rather closed expert discourse with moderate and radical critics marginalised. The dominant paradigm shared by business and financial markets experts and regulators included the assumption that the general trends towards higher structural complexity within the liberalised and deregulated markets were extremely positive and allowed unprecedented economies of scale and scope, increasing transnational activities, extreme leverage, and a focus on investment banking which would result in overall benefits for societies. That the ever larger financial institutions resulting from fast capital concentration through global competition, mergers and acquisitions would be more stable, because such institutions would be more diversified and superior in applying new risk measurement and management techniques, was another credo of the time. ${ }^{17}$ Within the European Union (EU) the demand for a highly integrated financial internal market with several global players was another key driver for ever more complex structures. Financial centres such as Wall Street or the City of London, as well as offshore centres, were highly respected and seen as positive drivers of globalisation contributing to more growth and

15 G B Gorton, Misunderstanding Financial Crises: Why We Don't See Them Coming (OUP 2012).

16 E Porter, 'Economists Agree: Solutions Are Elusive', New York Times (New York, 23 April 2013).

17 M Carey and R M Stulz (eds), The Risks of Financial Institutions (University of Chicago Press 2006). 
wealth across the planet. Financialisation - understood as the increased importance of financial motives, markets, actors and institutions - would allow all social groups and every individual to participate in this new world of better and more democratic access to financial products. The overall pre-crisis paradigm ignored systemic problems caused by the increasing complexity of structures, activities and products, extreme leverage, the increasing interconnectedness and size of financial institutions and reduced transparency. In particular, calls for a global systemic risk regulator receiving broader attention in the aftermaths of the East-Asian financial crisis of 1997-98 were ignored. Largely overlooked were also problems of unfair competition derived from subsidies for TBTF institutions, or the fact that various fast-growing markets, such as high-frequency trading or derivatives trading, were highly concentrated giving unfair advantages to specific market players, such as megabanks, highfrequency traders or the privileged 'primary dealers'. It is only in the post-meltdown climate that ever larger, more complex and more leveraged financial institutions and unregulated, market-driven innovation are no longer uncritically accepted by key regulators but seen as unacceptable causes for excessive risk-taking, excessive leverage, and inadequate capital requirements that altogether increase the probability of crises and bailouts.

Given poor evidence, it is rather odd how complex and opaque structures, products and activities and, in particular, high leverage and unregulated innovation are often presented as absolutely superior and essential for global markets. In 2009, Paul Volcker, a former chair of the US Federal Reserve and an outspoken critic of today's financial system, polemicised against this ideology-driven claim that the only useful innovation of modern finance was the automated teller machine (ATM) and that he would still await someone showing him evidence that modern finance would actually contribute to economic growth. ${ }^{18}$ In the UK, Adair Turner, then chair of the now dismantled Financial Services Authority (FSA), similarly concluded:

There is no clear evidence that the growth in the scale and complexity of the financial system in the rich developed world over the last twenty to thirty years has driven increased growth or stability, and it is possible for financial activity to extract rents from the real economy rather than to deliver economic value. ${ }^{19}$

Martin Wolf, chief economics commentator of the Financial Times, repeatedly argued that the crisis resulted from 'an illmanaged, irresponsible, highly concentrated and undercapitalised financial sector' and that we have to be really radical this time as the crisis so far brought us into a situation in which 'the most important point is that where we are now is intolerable'. ${ }^{20}$ Similarly, Sir Mervyn King, Governor of the Bank of England until mid-2013, stated in a speech:

Of all the many ways of organizing banking, the worst is the one we have today ... Change is ... inevitable. The question is only whether we can think our way through to a better outcome before the next generation is damaged by a future and bigger crisis. ${ }^{21}$

18 'Volcker Praises the ATM, Blasts Finance Execs, Experts', Wall Street Journal (New York, 8 December 2009); 'Paul Volcker: Think More Boldly', Wall Street Journal (New York, 14 December 2009).

19 A Turner, 'What Do Banks Do? Why Do Credit Booms and Busts Occur? What Can Public Policy Do About It?' in A Turner et al (eds), The Future of Finance: The LSE Report (London School of Economics 2010).

20 M Wolf, 'Narrow Banking Alone is Not the Answer', Financial Times (London, 15 December 2009).

21 M King, Banking: From Bagehot to Basel, and Back Again (Second Bagehot Lecture Buttonwood Gathering, New York City, 25 October 2010) (Bank of England 2010) <www.bankofengland.co.uk/publications/ Documents/speeches/2010/speech455.pdf>. 
In short, 'international policymakers have concluded that many of the world's largest banks are not the right size' and are now looking at ways to make banking structures more 'robust and resilient'. 22

One of the core questions in contemporary financial regulation reform debates is about the best - the optimum - structure for traditional banking to reduce systemic risk and to stop TBTF by removing any implicit or explicit government support for financial institutions (including the shadow banking system) that creates moral hazard and the necessity of bailouts by the taxpayer. In a functioning market economy, failing firms are expected to go into bankruptcy, which in turn improves the situation for the surviving businesses - this is why Joseph Schumpeter ${ }^{23}$ described this process as 'creative destruction' and a key driver of economic development. But TBTF seemed to make bailouts, state aid and mergers a necessity that generally led to further market concentration and market distortions. These trends have continued over the past few years. Moreover, an increase in mergers is already expected with market consolidation in a calmer post-crisis period. In the crisis situation, subsidies create the problem of the so-called zombie banks and various restrictions on legal action ('too big to jail') which not only undermine the functioning of the market but also the legitimacy of the capitalist system. Even by neoliberals these fundamental market distortions caused by implicit or explicit government support are understood as in urgent need of reform.

Deleveraging and less complex, more competitive and more transparent structures are regarded as necessary to reduce systemic risk and to design a more preventive and precautionary financial system. ${ }^{24}$ Yet, still only a minority wants to return to boring banking, or an even more radical overhaul of the financial structures. Ideas to redesign finance along the lines of strict product and activities regulations, such as - despite several flaws - is already the practice in drugs, food, or chemicals regulation in various regimes, did not find broad support either. Proposals, such as learning from Islamic banking, largely unaffected by the global crisis, were also only supported by a few. The majority of regulators and especially of business representatives still hope to get away with rather moderate adjustments. A too simple and restrictive system is by many seen as no longer adequate given global trade levels and interconnectedness and is often associated with a loss in overall consumer welfare. Hopes that this crisis could transform the system beyond financialisation are counteracted by significant fears that any such an attempt would go in a wrong direction or even that modest reforms would already go too far by creating more harms than goods, especially in this time of economic recovery in which finance is needed.

The question about the optimum structure is related to the insight that the industry structure has to be transformed by regulation and not just by post-crisis market or technology-driven processes that modify the structures of finance too. Changing industry structures via regulation and the right timing of this approach are, of course, highly contested. It is only logical that industry opposes any changes to a system that generates high returns and bonuses. Over recent years, there were numerous complaints from business lobbyists that policy-makers would wrongly follow a populist demand for

22 A G Haldane, On Being the Right Size (Bank of England, speech, Institute of Economic Affairs, Pall Mall, 25 October 2012) <www.bankofengland.co.uk/publications/Pages/speeches/default.aspx>.

23 J A Schumpeter, Capitalism, Socialism and Democracy (Routledge 1992).

24 J Crotty and G Epstein, 'A Financial Precautionary Principle: New Rules for Financial Product Safety' (Wall Street Watch Working Paper, No 1, Consumer Education Foundation 2009); D Pesendorfer, 'Goodbye Neoliberalism? Contested Policy Responses to Uncertain Consequences of the 2007-09 Financial Crisis' in K Alexander and R Dhumale (eds), Research Handbook on International Financial Regulation (Edward Elgar Publishing 2012) 414-34. 
punishing bankers resulting in over-regulation with disastrous effects on the financial sector's contributions to economic recovery. Further concerns are that, when not in line with international agreements, too ambitious reforms might just lead to economic disadvantages caused by regulatory competition on globalised financial markets and that policy-makers and regulators are limited in their actions by fears that institutions and activities would just move to other jurisdictions in response to tough regulation. Moreover, modest reforms are supported by contemporary regulatory practices. Opponents of more significant structural reforms frequently point towards high costs in such processes and uncertainties of measures, such as much stricter capital requirements, breaking up the largest institutions, controlling innovation, or more transparency. Good governance regulatory tools such as public consultations and Regulatory Impact Assessment with Benefit-Cost Analysis are only of a limited value in these discussions. Public consultations are dominated by the opinions of experts from the financial sector beside the various other 'behind-the-door' lobbying activities. ${ }^{25}$ Regulators are also often captured by business interests. ${ }^{26}$ It is moreover extremely hard to calculate any possible effects of structural reforms over the next few decades and all proposals necessarily include a high level of uncertainty. ${ }^{27}$ Frequently powerful lobbying groups intervened with calculations of the high costs of reforms, while ignoring the significant costs of the likely next crash and crisis. ${ }^{28}$ In short, we not only have insufficient evidence about the benefits and costs of the current financial system but also about the various options for its long-term transformation, which leaves decision-makers with a political decision about what the future of finance should look like and a normative decision about how much stability this will create and what risk-risk trade-offs are acceptable. And up to now, the political will for real reforms was mostly missing, as Admati and Hellwig lamented. ${ }^{29}$ In this climate, some observers have concluded that there has been little real change so far. Others have started to assume that the major decisions to shape the structures of finance for the next few decades have been made. For the US, Simon Johnson concluded: 'The debate is over; the decision to cap the size of the largest banks has been made. All that remains is to work out the details. ${ }^{30}$ What kind of decisions have been made and in what direction the reforms will go is the focus of the next section.

\section{Redesigning and transforming finance}

Structures of finance can be transformed directly or indirectly and either by building on existing regulation or by adopting new regulation. Indirect regulation affects the overall market dynamics by correcting incentives for specific products and activities that then affect market structures. Such price regulations are, for example, higher capital requirements or sector-specific taxes. Direct measures aim at regulating structures of financial institutions via institution-specific requirements. From among the numerous reforms of finance adopted or proposed over the past few years, this paper will focus on proposals to change the structure of finance directly via structural regulation. Given the adopted measures and proposals so far, divergence between the US and the EU, but even within EU member

25 Admati and Hellwig (n 2).

26 S Pagliari (ed), Making Good Financial Regulation: Towards a Policy Response to Regulatory Capture (Grosvenor House 2012).

27 See eg the Impact Assessment for the UK Financial Services Bill 2012.

28 S Johnson, 'The Impact of Higher Capital Requirements for Banks', New York Times Economix (New York, 18 April 2013); Oxford Economics, Analyzing the Impact of Bank. Capital and Liquidity Regulations on US Economic Growth (Clearing House and Oxford Economics 2013).

29 Admati and Hellwig (n 2).

30 S Johnson. 'The Debate on Bank Size Is Over', New York Times (New York) 28 March 2013. 
states, has become likely. However, numerous loopholes and flaws in regulations might make the differences less important as will be argued. Moreover, there have always been quite significant dissimilarities in the financial structures of these jurisdictions and some differences clearly accommodate the chosen regulatory paths. The most important ideas with regard to becoming in some form regulatory reality are the US approach linked to the Volcker Rule and the British/European reform proposal of ring-fencing, as well as reforms on orderly resolution. But there are also a number of other, more or less marginalised demands, such as opposition to interventions, 'narrow banking', limited purpose banking, or even further nationalisations of banks, that need to be explored given the dynamics of a crisis that might allow 'radical' proposals to become dominant. This section will discuss these ideas with regard to their overall effects including those related to regulatory competition, intended and unintended consequences, possible weaknesses, and flaws and loopholes in order to ask whether any of these proposals is radical enough to make the financial system safer and to achieve the stated goals.

\subsection{NO REGULATION OF INDUSTRY STRUCTURES}

One of the major claims in this discourse is that in a situation of high uncertainty any new regulation would generate highly negative unintended consequences. Most neoliberals share the belief that governments should not intervene and try to change or design market structures. This should be solely left to market forces, whereby one market-based solution to deal with systemic risk might be to force firms to buy insurance against its potential losses. ${ }^{31}$ They also argue against bailouts or more interventionist merger control and many other measures that would affect the structures of finance. In the current historical situation, without a quick recovery and a return to pre-crisis conditions, the nonintervention demand is damned to remain ideology as neither firms nor regulators were highly supportive of radical market-based solutions. The argument with regard to structural reforms has therefore slightly shifted to emphasising that banking regulation has already been strongly strengthened via Basel III (still in need of fine-tuning and implementation) and that market-driven and corporate governance reforms have already brought significant changes in behaviour that all together will make banks safe enough. Structural reforms are now 'untimely' and would only harm economic recovery. Moreover, many bankers have claimed that structural reforms always pose assessment problems and would necessarily lead to negative unintended consequences. In the UK, they have emphasised that it would not have been the largest institutions that got into trouble and mega-size would not automatically translate into excessive risk. Similarly, in the US JPMorgan Chase was an often-used example of a big institution getting through the crisis without serious problems and its chief executive officer Jamie Dimon became the most prominent opponent against reform calls. However, how well such institutions performed during the crisis is not relevant for the question of how they contribute to a too high systemic risk level. Also regulators are looking at this issue and have concluded that size of the balance sheet alone is an insufficient indicator to capture problems related to more complex interconnections. ${ }^{32}$

In the US, Mitt Romney's defeat in the 2012 presidential elections ensured that structural reforms adopted with the Dodd-Frank Act 2010 will not be achieved for at least another four years. However, Republicans were successful in blocking proposals that regulators get sufficient funding for implementing reforms and worked actively towards delaying

31 V V Acharya et al, 'Regulating Systemic Risk' in V V Acharya and M Richardson (eds), Restoring Financial Stability: How to Repair a Failed System (John Wiley \& Sons 2009) 283-303.

32 Eg the European Central Bank for this purpose developed a framework for identifying 'large and complex banking groups'. 
implementation. In the EU, where reforms have been slowed down because of the Eurozone crisis, the general acceptance for structural reforms is not necessarily higher with the UK highly concerned about the overall future competitiveness of London and with Germany and France also interested in improving their competitive position in global finance. With the European crisis, market-driven developments led to decreased transnational activities of banks and to problems meeting stricter capital requirements. Nevertheless, all the above-mentioned countries have put forward direct regulations affecting the future structures of finance. For Europe one could, of course, argue that a non-intervention position has already been strengthened over the past years with the 'modernisation' of European competition law and policy that brought the European approach closer to the Chicago School theory and away from interventions into markets in favour of deepening integration. Competition law is powerful and in its neoliberal interpretation on both sides of the Atlantic superior to other public policy goals. In the EU the unique state aid policy assures, moreover, that any state aid requires strict restructuring obligations. ${ }^{33}$ Beyond the rather limited state aid policies, the framework largely favours non-intervention into the market mechanism. But, for now, the US is implementing the Volcker Rule, incorporated into the Dodd-Frank Act, and the EU Commission and the UK proposed ring-fencing as most important structural reforms, whereby the EU approach is more similar to the Volcker Rule and has recently been adopted by Germany in a new Banking Separation Act. 34

\subsection{From Glass-Steagall to the Volcker Rule}

In the early 1930s climate of political and economic turmoil in the US, a debate had started about separating commercial and investment banking. President Hoover and Senator Carter Glass became advocates of this idea, sharing the analysis that this would solve problems that led to the stock market crash by eliminating various conflicts of interests and high-risk speculative lending practices. Representative Henry B Steagall was an advocate of deposit insurance to make banks safer. The reform proposals were finally also accepted by investment and commercial banks that saw at least temporary advantages in the final proposals. ${ }^{35}$ The Banking Act of 1933, often referred to as the Glass-Steagall Act, was then the law establishing federal deposit insurance and various restrictions on speculation and splitting investment and commercial banking. Glass-Steagall's original intention was to bring all commercial banks under the Federal Reserve System and to establish strict restrictions on speculation. However, thanks to loopholes, a large number of state chartered banks remained outside this system, putting them also outside the restrictions on purchasing and selling securities. From the 1960 s, the restrictions were already being interpreted less strictly and commercial banks were more and more allowed to engage in securities activities and, since the 1980s, investment banks have increased their engagement in thrifts or state chartered banks, avoiding Glass-Steagall affiliation restrictions and holding company laws. It nevertheless took until 1999, when under President Bill Clinton the Gramm-Leach-Bliley Act was adopted that removed the remaining barriers for commercial banks to engage in investment banking or to merge with insurance companies. The Glass-Steagall provisions against conflicts of interest were no longer seen as adequate regulation in modern financial markets but as unnecessary restrictions reducing market efficiency and liquidity and putting

33 U Soltész and C Von Köckritz, 'From State Aid Control to the Regulation of the European Banking System: DG Comp and the Restructuring of Banks' (2010) 6(1) European Competition Journal 285.

34 Gesetz zur Abschirmung von Risiken und zur Planung der Sanierung und Abwicklung von Kreditinstituten und Finanzgruppen, 17 May 2013.

35 V V Acharya et al, 'A Bird's-Eye View: The Financial Crisis of 2007-2009' in Acharya and Richardson (n 31). 
US banks into competitive disadvantage. However, there were also early warnings that Gramm-Leach-Bliley would go too far and increase the TBTF problem. ${ }^{36}$ But it was only in the aftermath of the financial meltdown that claims became widely popular that repealing Glass-Steagall was a major cause of the financial crisis and that commercial and investment banking should be split again. Only a few have argued for reintroducing Glass-Steagall and the dominant approach became a moderate reformulation under the label 'Volcker Rule'.

The Volcker Rule, named after Paul A Volcker, a former Federal Reserve chair from 1979 to 1987 who championed the idea of breaking up the largest banks and prohibiting deposit-taking institutions from engaging in certain forms of risky activities, will restrict banks from speculating with federally insured deposits. More specifically, the rule prohibits bank holding companies from owning, investing in or sponsoring hedge funds or private equity funds and from engaging in proprietary trading. Volcker regards this measure as key in the interest of fair and open competition as well as protecting the provision of essential financial services'. ${ }^{37}$ This rule became a prominent cornerstone of US regulatory debates. President Obama proposed it in January 2010 as an integral part of the financial regulatory overhaul. ${ }^{38}$ A House-Senate conference committee then approved the rule in June 2010. ${ }^{39}$

Originally, Volcker outlined the rule 'in a three-page letter to the president'. In 2010, when the Dodd-Frank Act 'went to Congress, the Volcker Rule that it contained took up 10 pages'; in its public consultation version in October 2011 it was 298 pages, 'accompanied by more than 1,300 questions about 400 topics'. ${ }^{40}$

The Dodd-Frank Act sets out the Volcker Rule in s 619. The proprietary trading provisions in the Act prohibit:

a banking entity or nonbank financial company supervised by the Board' from trading activity in which it acts as a principal (principal investments) for its own trading account in any transaction to purchase or sell, or otherwise acquire or dispose of, any security, any derivative, any contract of sale of a commodity for future delivery, any option on any such security, derivative or contract, or any other security or financial instrument that the appropriate federal banking agencies, the Securities and Exchange Commission (SEC), and the Commodity Futures Trading Commission (CFTC) may, by rule as provided in subsection (b)(2), determine.

The hedge fund and private equity fund provisions generally prohibit deposit-taking institutions to 'acquire or retain any equity, partnership, or other ownership interest in or sponsor a hedge fund or a private equity fund'. ${ }^{41}$

The Volcker Rule version in the Dodd-Frank Act was watered down compared to earlier formulations and included several exemptions. Although the rule bans banks from shortterm trading of securities for their own account and limits investments in private equity groups and hedge funds, the restrictions allow a number of exemptions that have been defined as 'permitted activities' and longer-term commitments or 'principal investments'. These activities include 'hedging', 'market-making', asset management, underwriting, and

36 G Stern and R Feldman, Too Big to Fail: The Hazards of Bank Bailouts (Brookings Institution Press 2009).

37 P Volcker, Probibiting Certain High-Risk Investment Activities by Banks and Bank. Holding Companies (Testimony before the Senate Committee on Banking, Housing and Urban Affairs, Washington DC, 2 February 2010).

38 New York. Times (New York, 23 January 2010).

39 New York Times (New York, 26 June 2010).

40 New York Times (New York, 21 October 2011)

41 Dodd-Frank Act, SEC 619, s 13(a)(1)(B). 
other transactions on behalf of customers. The line between these activities and purely speculative activities is highly flawed. For this reason Dodd-Frank is sometimes also labelled 'Glass-Steagall lite'.

The Dodd-Frank Act demanded the Financial Stability Oversight Council (FSOC) to study the implementation of the Volcker Rule and to make corresponding recommendations 'not later than 6 months after the date of enactment'. The FSOC published its report in September 2011.42 All the details of the rule's implementation were left by Dodd-Frank to the regulatory authorities (SEC, CFTC, Office of the Comptroller of the Currency, Federal Deposit Insurance Corporation, and the Board of Governors of the Federal Reserve System). The agencies would have been required to adopt implementation rules not later than nine months after the Financial Stability Oversight Council's study's completion. However, decision-making was slowed down by massive lobbying interventions and highly technical consultations. Critics insisting on a strict implementation were more and more marginalised between 2010 and 2012. The Republicans openly demanded dropping the Volcker Rule completely as part of their demand for reversing Dodd-Frank's over-regulation. Republicans argued in particular that the Volcker Rule would put US banks into clear competitive disadvantages on the global market. ${ }^{43}$ They fought against a strict implementation in the US congressional bank oversight panel and by threats to block or reduce budgets for the agencies that will have to implement the Volcker Rule.

The final version was still delayed when, in May 2012, JPMorgan Chase had to disclose a $\$ 2$ billion trading loss (later turning out to be an at least $\$ 6.2$ billion loss) ) $^{44}$ that was broadly interpreted as strong evidence for the lack of change at Wall Street banks and their ongoing gambling that could only give advocates of a stricter implementation of the Volcker Rule a massive boost. In particular JPMorgan's loss led to debates about how this rule would have had an impact on such deals, had it already been in force, although JPMorgan did not release any details behind the trade. However, the flawed interpretations of hedging and market-making still allowing high-risk speculation and the consequences from weakening implementation gained attention. The FSOC had already emphasised the importance of reviewing 'permitted activities' closely and to implement a 'programmatic compliance regime' that would need to be 'designed to ensure that proprietary trading does not migrate into permitted activities' ${ }^{45}$ But with the JPMorgan loss scandal, demonstrating poor risk management in the top bank and the success of the large banks in interpreting 'hedging' and 'market-making' to their advantage, stricter implementation became at least for the moment more likely. The timing of this debacle was perfect for advocates as the final version of the Volcker Rule was expected by the summer or at least by early fall. This was an example of how business power, regulatory capture and regulatory competition pressures can become weaker under conditions of crisis, when the capacity for gradual institutional change exists. However, it is also an example of how the financial regulation elite still do not bother about huge profits coming from the same risky activities, but are surprised if things go wrong.

Compared to Glass-Steagall, the Volcker Rule is overly detailed and complex. Luigi Zingales became one of the few advocates for Glass-Steagall arguing that it is superior thanks to its simplicity and necessary for 'a well regulated and transparent public market':

42 FSOC, Study and Recommendations on Probibitions on Proprietary Trading and Certain Relationships with Hedge Funds and Private Equity Funds (FSOC 2011).

43 Reuters, 4 November 2010.

44 Senate Permanent Subcommittee on Investigations, 'JPMorgan Chase Whale Trades: A Case History of Derivatives Risks and Abuses' (Permanent Subcommittee on Investigations, 15 March 2013).

45 FSOC (n 42). 
The Glass-Steagall Act was just 37 pages long. The so-called Volcker rule has been transformed into 298 pages of mumbo jumbo, which will require armies of lawyers to interpret. The simpler a rule is, the fewer provisions there are and the less it costs to enforce them. The simpler it is, the easier it is for voters to understand and voice their opinions accordingly. Finally, the simpler it is, the more difficult it is for someone with vested interests to get away with distorting some obscure facet.

In Zingales' view, 'Glass-Steagall helped restrain the political power of banks' and was an important law against 'excessive power.' ${ }^{46}$ With the Glass-Steagall, provisions investment banks, commercial banks and insurance companies would have different interests and agendas that would limit their overall power by off-setting one another.

Overall the highly controversial US debate reflects the huge uncertainties with regard to direct regulations that will shape the future of finance and that the current policy is not going beyond financialisation.

\subsection{RING-FENCING}

While the Volcker Rule is very much embedded in the US regulatory culture and memory of Glass-Steagall and in a strong antitrust policy concern against TBTF institutions, the idea gained much less support in Europe, where many countries have no history of a separation between retail and investment banking but extensive experience with universal banking. Inspired by a study by the Organization for Economic Co-operation and Development, ${ }^{47}$ this led to proposals focusing on ring-fencing certain business areas by the UK Independent Commission on Banking (ICB) and by the European Commission's High-level Expert Group on reforming the structure of the EU banking sector.

In the UK, the Volcker Rule has mostly been criticised as the wrong approach. The largest banks argued that the crisis would not show a clear relationship between bank size and activities but only a relationship between good and bad risk management practices. Deposit-taking institutions engaged in propriety trading and investing in hedge funds and private equity groups would provide useful services. The governments supported this view. Before forming a Coalition government, many Conservatives and Liberals were more critical about banking structures. George Osborne, then Shadow Chancellor, called for a sector with smaller banks. While former Prime Minister Gordon Brown rejected a 'rigid divide' of banks along a Glass-Steagall approach, Osborne argued that British banks had become TBTF and too big to be bailed out. ${ }^{48}$ However, the Conservatives did not want to position themselves too early with precise plans. Their manifesto for the 2010 general election announced that they would 'pursue international agreement to prevent retail banks from engaging in activities, such as large-scale proprietary trading, that put the stability of the system at risk'. The Liberal Party, especially Vince Cable, called for a total separation of the retail banks from 'casino' investment banks. The coalition agreement between the Conservatives and Liberals, released on 12 May 2010, promised 'detailed proposals to foster diversity, promote mutuals and create a more competitive banking industry'. In order 'to reduce systemic risk in the banking system' they announced that they would 'establish an independent commission to investigate the complex issue of separating retail and investment banking in a sustainable way' within one year. On 16 June 2010, Chancellor Osborne announced the creation of this ICB chaired by Sir John Vickers.

46 L Zingales. 'Why I Was Won Over by the Merits of Glass-Steagall', Financial Times (London, 11 June 2012).

47 A Blundell-Wignall, G Wehinger and P Slovik 'The Elephant in the Room: The Need to Deal with What Banks Do', Financial Market Trends (OECD 2009).

48 Financial Times (London, 24 February 2009). 
The ICB was a rather small commission, with two out of five members having had past or continued clear affiliation with financial firms. After taking up work, the ICB released an 'issue paper: call for evidence' in September 2010 that discussed a number of issues such as financial stability, competition, economic recovery and lending, competitiveness, and risks to the government's fiscal position, and presented reform options for consultation. The latter included options related to the structure of banks. These included the 'separation of retail and investment banking', à la Glass-Steagall, 'narrow banking and limited purpose banking', 'limits on proprietary trading and investing' in line with the Dodd-Frank Act's Volcker Rule, the degree of separation, structural separability, contingent capital, and structure-related surcharges. With regard to the structure of financial markets the ICB considered 'measures to reduce concentration' related to merger law and a market infrastructure reform with the goal of increased transparency. Against a Volcker Rule type of limits on proprietary trading and investing, the ICB argued that:

there is the practical question of how to tell the difference between proprietary trading on the one hand, and risk-reducing hedging or market-making on the other. For example, a bank might acquire a large position in interest rate swaps for speculative reasons or, by contrast, to hedge interest rate risk naturally arising from the maturity transformation of ordinary commercial banking business. ${ }^{49}$

The ICB then accepted the arguments against a break-up of TBTF banks and proposed alternatively the idea of ring-fencing to protect retail banking from the investment banking divisions. ${ }^{50}$ Banks would have to put their high-street banking in a separate legal subsidiary with higher capital requirements and an independent board. Instead of a total separation of retail and investment banking: both subsidiaries could remain under a common parent holding company. Banks would have some flexibility to decide what is inside and outside the higher protected retail part. The proposals should be implemented by 2019 .

In total, the IBC believes that: 'Ring-fenced banks would be simpler, less connected and easier to resolve without taxpayer support than existing universal banks. ${ }^{51}$

While the UK government supported the idea, ring-fencing has also been heavily criticised. The director-general of the Confederation of British Industry called it, in a Financial Times interview, 'barking mad'. ${ }^{52}$ Industry and lobbyists have argued that ringfencing would lead to banks becoming uncompetitive and harm the chances of a recovery. Others called for high flexibility to ensure that the UK banks would not become uncompetitive against global competitors or argued that Basel III rules would be much more significant. ${ }^{53}$ There was also some concern in the financial press over whether ringfencing could work in practice.

After the Queen's Speech in May 2012 confirmed that the government would go ahead with the controversial measures within a Banking Reform Bill, ${ }^{54}$ banks warned that plans to ring-fence would be too expensive and the costs would be passed on to businesses and household customers. ${ }^{55}$ As a next step, the Treasury and the Department for Business, Innovation and Skills presented a White Paper entitled Banking Reform: Delivering Stability and

49 ICB, 'Issue Paper: Call for Evidence' (ICB 2010) 34.

50 ICB, Final Report: Recommendations (ICB, September 2011).

51 Ibid 48.

52 Financial Times (London, 29 August 2011).

53 G Mathewson 'Ringfencing not Real Threat to Britain', Financial Times (London, 11 September 2011).

54 Financial Services (Banking Reform) Bill, Bill 002 2013-14.

55 <www.moneymarketing.co.uk/regulation/-rbs-chief-says-customers-will-pay-ringfencing-costs/ $1051312>$ accessed 14 May 2012. 
Supporting a Sustainable Economy that opened the next round of public consultation. Besides setting out the context of the reforms, the White Paper discusses ring-fencing, lossabsorbency and competition in separate chapters. It also presents in the annex an impact assessment comparing the benefits and costs of the Coalition government's implementation plan of the IBC recommendations with a reference policy option of non-action.

Vickers criticised the government saying that the proposal would not go far enough and fall short of fully implementing the recommendations of the IBC, especially watering down the limits on the leverage of big banks. ${ }^{56}$

Throughout the debates initiated by the establishment of an IBC and the consultation processes on an initial call for evidence and then on the interim report, there were warnings that the UK should not adopt any approach unilaterally but 'should lead a global debate on structural reform'. ${ }^{57}$ Industry was generally in opposition of any limits on proprietary trading and investing, arguing for market efficiency and the need for hedging and marketmaking. ${ }^{58}$ Barclays ${ }^{59}$ argued that there would not be any evidence suggesting 'that structural change would enhance financial stability', the costs for structural change would be too high and implementation uncertain. Structural changes with regard to diversity of business models, size and types of banks should be left to the market and the institutions themselves. Any changes should conform to international reforms with regard to scope and timeline. The British Bankers Association (BBA) ${ }^{60}$ defended universal banks, emphasising their key role in economic recovery. Moreover, the BBA warned 'that separately devised national measures or international measures introduced on a super-equivalent basis in the UK will not only have the potential to be detrimental to the UK's attractiveness as a financial centre, but also be damaging to the economic future of the UK'. HSBC ${ }^{61}$ advocated the universal banking model as 'best placed to meet 21 st century needs'. Moreover they would be 'more stable' than other forms of banks. In summary these arguments are the pre-crisis arguments claiming advantages of financialisation.

Following the interim report and the final report, industry remained concerned about the ICB's ring-fencing proposal. Critique included the argument that it would be too costly with a negative impact on recovery, that it would increase the stress on the unprotected entity in times of crisis, ${ }^{62}$ or that ring-fencing should not be designed in a way that it has impacts on any of the current 'standard banking services demanded by their individual and business customers of any size'. ${ }^{63}$ The BBA has also been concerned about ring-fencing and demanded much more evidence and research on 'the effect of such a proposal on financial stability under different economic scenarios' as well as 'the consequences for the internationality of the UK as a financial centre should such a proposal proceed.'64

This is all evidence of a weakened banking industry. However, Angela Knight, chief executive of the BBA, eventually welcomed the banking reform White Paper stating that it

56 Guardian (London, 14 June 2012).

57 Augar, Evidence to the ICB, 15 November 2010. All following evidence papers are available on the ICB website <http://bankingcommission.independent.gov.uk/responses/>.

$58 \mathrm{Eg}$ Association for Financial Markets in Europe evidence to the ICB, 19 November 2010.

59 Evidence to the ICB, 15 November 2010.

60 BBA, evidence to the ICB, 15 November 2010.

61 Evidence to the ICB, 24 November 2010.

62 See eg the Royal Bank of Scotland's response to the Interim Report, 4 July 2011. The responses to the ICB Interim Report are available at the ICB website <http://bankingcommission.independent.gov.uk/ interimresponses $/>$.

63 Santander Response to the Interim Report (n 62).

64 BBA Response to the Interim Report (n 62). 
'balances the need to establish a banking system which is more certain and more secure with the ability of banks to continue to provide the full range of services to customers and support to the economy'. The BBA especially welcomed 'the refinements to the original proposal', which in total would 'have removed many of the obstacles from the original [ICB] report'. Although 'the costs to the banks' would still be 'substantial', Knight no longer saw a risk for the provision of services or the City's international position. ${ }^{65}$

Since then the Parliamentary Commission on Banking Standards has concluded that the ring-fence proposals are insufficient, because there would not be sufficient precautions to ensure that the ring-fence does not get holes over time via lobbying and political interventions. The Parliamentary Commission therefore suggested 'electrification' of the ring-fence. The regulator would need strong powers to enforce separation of institutions if they do not meet strict ring-fence requirements. This would also require periodic reviews of the sector, and over time even tougher measures might be required. As next task the Parliamentary Commission wanted to look into full separation of proprietary trading along the Volcker Rule line. ${ }^{66}$ These proposals go in an interesting direction from the perspective of gradual institutional change and address typical problems of financial reforms becoming less strict in implementation and enforcement over time.

A slightly different approach to ring-fencing comes from the EU's High-level Expert Group on reforming the structure of the EU banking sector. The group was set up by Commissioner Michel Barnier in November 2011 to assess the need for bank structural reforms and it was chaired by Erkki Liikanen, Governor of the Bank of Finland. The group held a consultation in May 2012 to which mostly banks and bank associations but also Finance Watch, Friends of the Earth Europe, and Transparency International responded. Contributions from megabanks were largely missing. The group's final report, released on 2 October 2012, proposed a mandatory separation of certain trading-related activities (above a specific threshold) which would require banking groups to organise certain businesses into a separate legal entity that must be separately capitalised and must not be funded by insured deposits. ${ }^{67}$ In contrast to the ICB position, the idea here is to ring-fence the investment banking arm with the trading and market-making arms.

The Liikanen Report was welcomed by Commissioner Barnier and was put out for a sixweek consultation. Among first reactions, industry representatives welcomed that the report did not put into question the universal banking model. But the hybrid between Volcker and Vickers was also seen as problematic by many industry representatives. Some argued that this reform could damage the flow of corporate funding in Europe. ${ }^{68}$ The next months will show reactions to the report and what will be translated into new regulations. In the meantime, this approach has been followed by Germany. The German Banking Separation Act, to be implemented by mid-2015, has, however, similar exemptions to the Dodd-Frank Act with regard to market-making and dealing on behalf of customers. The German approach might guide the direction for other countries with a strong universal banking tradition. In summary, the developments on ring-fencing led to policies to modify the existing structures only moderately and to keep important loopholes that do not undermine

$65<$ www.bba.org.uk/media/article/angela-knight-banking-reform-white-paper-balance-safety-with-the-needsof-g>, 14 June 2012.

66 House of Lords-House of Commons Parliamentary Commission on Banking Standards, First Report Together with Formal Minutes, vol I (HL 201298 HC 2012 848) (The Stationery Office 2012).

67 E Liikanen et al, High-level Expert Group on Reforming the Structure of the EU Banking Sector: Final Report (Brussels, 2 October 2012).

68 Financial Times (London, 8 October 2012). 
the dominance of financialisation. Loopholes and flaws are similar to the US approach and can be explained by massive business pressure and fears about competitive disadvantages.

\subsection{NARROW BANKING}

A third proposal to end bailouts of financial institutions is narrow banking. This idea has its origins in the US where it was previously considered in the 1930s. It is based on the belief that the fractional reserve banking system would have significant problems and weaknesses and that it would only work in normal times. Whenever faced with extraordinary demand for cash, banks would necessarily face bank runs, break down or require bailouts. In the 1930s, economists at the University of Chicago proposed the 'Chicago Plan' and Yale economist Irving Fisher suggested a '100 percent money' system. ${ }^{69}$ The core idea of these proposals was to split the banking system into a protected commercial banking system and a risky investment banking system. Milton Friedman also became an advocate of narrow banking when he updated the Chicago Plan. ${ }^{70}$ Since then, narrow banking has remained a topic that again and again gained some attention. In the 1980s, Robert Litan of the Brookings Institution proposed narrow banking to deal with moral hazard. ${ }^{71} \mathrm{His}$ idea was to create monetary service companies that would only hold safe assets. Ronnie Philips discussed not just the advantages of narrow banking but also engaged with critics. ${ }^{72}$ Another important study was an International Monetary Fund working paper entitled 'Should Banks Be Narrowed?' that argued that narrow banking would result in 'less than certain benefits in terms of greater financial stability, while it would exact some heavy costs in terms of efficiency and credit availability. ${ }^{73}$

Now, in the aftermath of the financial meltdown, narrow banking has again found some wider support. Phillips and Roselli proposed narrow banking for the US. ${ }^{74}$ John Kay, a Scottish economist, professor at the London School of Economics and Financial Times columnist, is the strongest supporter of narrow banking in the UK. According to Kay, the purpose of narrow banking 'is to protect the non-financial sector as far as possible from the consequences of failures and instability within the financial sector'. This would only be possible by a complete separation of 'the casino from the utility'. ${ }^{75}$

Advocates of narrow banking share the belief that better or more regulation will not prevent financial institutions from excessive risk-taking. Supervision would be the wrong approach and narrow banking would require only limited regulation. Kay, for example, stated that the principles should be 'competition where possible, regulation where necessary, and supervision not at all'. ${ }^{76}$ This distaste of supervision comes from the belief that it is necessarily resulting in regulatory capture. ${ }^{77}$

69 I Fisher, 100\% Money (City Printing Company 1935); I Fisher, '100\% Money and the Public Debt' [1936] (April-June) Economic Forum.

70 M Friedman, A Program for Monetary Stability (Fordham UP 1960).

71 R E Litan, What Should Banks Do? (The Brookings Institution 1987).

72 R Phillips, Narrow Banking Reconsidered: The Functional Approach to Financial Reform (Levy Institute Public Policy Brief, no 18/1995) <www.levyinstitute.org/pubs/ppb17.pdf>.

73 B Bassone, 'Should Banks Be Narrowed?' (IMF Working Paper WP/01/159 2001).

74 R Phillips and A Roselli, How to Avoid the Next Taxpayer Bailout of the Financial System: The Narrow Banking Proposal (Networks Financial Institute Policy Brief 2009-PB-05) available at SSRN $<$ http://ssrn.com/abstract $=1459065>$.

75 J Kay, 'Narrow Banking: The Reform of Banking Regulation' <www.johnkay.com/wp-content/ uploads/2009/12/JK-Narrow-Banking.pdf>; J Kay, 'Should We Have “Narrow Banking”?' in Turner et al (n 19).

76 Kay, 'Should We Have “Narrow Banking”?’ (n 75) 212.

77 Ibid 210. 
The idea of narrow banking found little support in regulatory reforms. It was nevertheless discussed in financial media, several economists expressed sympathies and also the UK ICB looked into it and asked for comments from stakeholders. In its 2010 issue paper' the ICB framed the debate with several concerns against narrow banking, such as lost synergy effects between deposit-taking and bank lending activities, a 'tying up' of 'banking deposits in government bonds' instead of making them 'available to fund productive investment through financial intermediation'. Moreover, narrow banking would not end the possibility and need for bailouts. ${ }^{78}$ In the final report, the ICB argued that narrow banking 'would dramatically reduce the range of intermediation possibilities' and that 'ring-fencing would be less costly. ${ }^{79}$ Kay himself discusses and rejects a number of critiques such as the claim that the world would need big banks, that big banks would be superior because of their ability to reduce risks by diversification, or that corporate customers would demand universal banking. He also opposed the claim that the unilateral introduction of narrow banking would result in competitive disadvantages. He also argues that 'living wills' and a proper resolution regime for insolvent banks would require 'radical restructuring and simplification of the corporate structures of financial conglomerates', resulting in narrow banking. ${ }^{80}$

However, throughout the ICB consultations there was no big support for narrow banking. HSBC dealt with narrow banking in an annex and claimed that it 'would be a retrograde step' and that it would be 'a primitive and costly model that would cause the cost of lending to rise significantly'. The concept would also ignore the market demand for 'more sophisticated products'. As a result, the corresponding risk of such products would simply shift 'somewhere else in the system' ${ }^{81}$ In short, narrow banking is an idea that would lead to a radical transformation of banking but which would require a radicalisation in the overall political debates for realisation. Then it would still compete with other radical ideas.

\subsection{LIMITED PURPOSE BANKING}

Another radical minority demand to end casino banking is the introduction of limited purpose banking. Here the argument is that narrow banking would not go far enough and would still invite 'all the problems of shadow banking' but that there would be a very simple way of making the banking system safe and ending financial collapse and contagion by transforming the system in line with the experience with mutual funds. Laurence Kotlikoff, professor of economics at Boston University, advocates the idea. ${ }^{82} \mathrm{He}$ argued in an open letter to Sir John Vickers, published in the Financial Times that:

Under Limited Purpose Banking, there are no incorporated shadow banks because all incorporated financial companies, whether they call themselves commercial banks, investment banks, hedge funds, SIVs, insurance companies, etc., are forced to operate in one way only - as mutual fund companies, which issue mutual funds with absolutely zero leverage, including no short positions. ${ }^{83}$

Financial companies would need to decide whether they operate with limited or unlimited liability. Under limited liability, firms would operate 'as 100 per cent equity-financed mutual funds' and they would only be allowed to engage in activities that do not involve leverage.

78 ICB (n 49) $33 \mathrm{ff}$.

79 ICB (n 50) 137.

80 <www.johnkay.com/wp-content/uploads/2009/09/Narrow-Banking-FAQs-Jan2010.pdf>.

81 Evidence to the ICB, 24 November 2010 (n 57).

82 L J Kotlikoff, Jimmy Stewart Is Dead (John Wiley \& Sons 2010); L J Kotlikoff and E Leamer, 'A Banking System We Can Trust' Forbes, 23 April 2009 <www.forbes.com/2009/04/22/loan-mortgage-mutual-fund-wall-streetopinions-contributors-bank.html $>$.

83 Financial Times (London, 28 January 2011). 
As their purpose is limited to financial intermediation, risk-taking shifts from the companies to individuals.

Kotlikoff assumes significant consequences of such a change, including the disappearance of shadow banking and risky speculation of firms with unlimited liability when 'the 'brilliant' titans of Wall Street who produced the financial debacle' would have to fear losing 'their homes, villas, yachts, Austin Martins, etc' ${ }^{84} \mathrm{He}$ also claims that a mutual funds system could never fail and that such institutions would only act, as intermediaries as kind of 'honest middle men'. In his view, the problem of modern finance is not about complex financial products but about systemic large-scale, multifaceted fraud and lack of information disclosure. These problems could be overcome by limited purpose banking and a federal regulator assuring strict control and full, real-time information disclosure. This new federal regulator he labels Federal Financial Authority (FFA) and is designed similar to the US Food and Drug Administration. The FFA would rate financial securities, the safety of investment banks, insurance companies, hedge funds and commercial banks. ${ }^{85}$

Limited purpose banking was also a topic in the UK ICB consultations. The 2010 issue paper stated that this alternative 'is open to some of the same criticism as narrow banking', that it would be too costly and that participating households would be negatively affected by the increase of illiquid assets. HSBC argued that the already existing limited purpose banking would show that it 'depends on the existence of a modern banking system': 'Without banks to originate the loans, package them into securities and distribute them to mutual funds, "limited purpose banking" could not take place'. Moreover, HSBC recalled weaknesses of money market mutual funds that had come to light over recent years and been addressed by the Dodd-Frank Act. ${ }^{86}$ In short, this is another idea that would require a completely different situation to gain more attention and will definitely not come via any form of gradual change.

\subsection{NATIONALISATION OF BANKS AND DEMOCRATIC CONTROL}

Over the past few years quite a number of troubled banks have had to be nationalised. Politicians were more than keen to emphasise that this was an extraordinary and temporary measure that should not be perceived as going back to pre-1970s state industries approaches. Nationalisation was the emergency step in a situation in which no private investor was willing to take over the risk. Alan Greenspan, for example, argued 'that once in a hundred years this is what you do' ${ }^{87}$ State actors underlined that the nationalised banks should be privatised as soon as the possible. Since then a debate has started over whether the state should use this new situation to gain a maximum return by keeping them much longer as state property or by using them as examples for transforming banking in a broader societal public interest direction. Additionally to nationalisations, massive debts of the private sector have been socialised and transformed into public debt. Some commentators, such as Martin Wolf, have argued that all the bailouts have already abolished the state-private divide and made banking strongly linked to the state which would legitimise the state to intervene much more aggressively. The most radical proposal, however, is the nationalisation - or better socialisation - of banks and putting them under democratic control. This is a demand, by some in the Occupy and labour movements and by Marxists, that signifies a major transition of existing varieties of capitalism and is normally linked with a less evolutionary and more revolutionary socialist or communist transitional

84 Financial Times (n 83).

85 <www.kotlikoff.net/content/interview-limited-purpose-banking>.

86 Evidence to the ICB, 24 November 2010 (n 57).

87 Financial Times (London, 18 February 2009). 
programme. But environmentalists have also been arguing for societal control over banking to incorporate sustainability principles. Historically, Marx and Engels called for 'centralisation of money and credit in the hands of the state, by means of a national bank with state capital and an exclusive monopoly', meaning 'the suppression of all private banks and bankers'. This measure was supposed 'to regulate the credit system in the interest of the people as a whole' and to 'undermine the dominion of the big financial magnates'. ${ }^{88}$ The demand was then a key aspect in the Bolshevik programme formulated in Lenin's April Theses and in his brochure on 'the impending catastrophe and how to combat it', both from 1917. The April Theses called for the 'immediate union of all banks in the country into a single national bank, and the institution of control over it by the Soviet of Workers' Deputies'. ${ }^{89}$ In the 'impending catastrophe', Lenin argued that the nationalisation of banks and their concentration into a single state bank is the only measure allowing a democratic control over finance given its complexity and the various accounting tricks. It would allow for the possibility 'to regulate economic life' and allow economic development without 'skyhigh' profits for bankers. 'Banks nowadays', he stated, 'are so closely and intimately bound up with trade (in grain and everything else) and with industry that without "laying hands" on the banks nothing of any value, nothing "revolutionary-democratic", can be accomplished'. 90

The nationalisation of banks and their transformation into a single state bank was seen as an easy task to be achieved by a simple degree and 'carried out by the directors and employees themselves'. Bankers resisting this change 'would lose their highly remunerative posts and the opportunity of performing highly profitable fraudulent operations'. It would also be necessary to confiscate their property and to imprison bankers, board members and big shareholders if they tried 'to conceal documents and accounts'. According to this transition programme, there would still be a market and the new banking structure would provide 'credit on easy terms for the small owners' and 'for the peasants'.91

It is obvious why such a programme should become to a certain extent popular again in a situation of deep economic crisis with high unemployment and unpopularity of bankers and why nationalisation and democratic control could at least theoretically be seen as necessary for a policy in the interests of the majority. Of course, proponents have drawn lessons from banking in eastern European countries under Soviet influence. Trotskyists still argue in line with Lenin and the debates of the early 1920s for a state monopoly under democratic workers' control. Other left-wing groups no longer call for a state monopoly and some have even wondered if the property question is relevant at all in a modern context and if democratic control could actually be achieved over private banks.

Nationalisation and democratic control have been demanded by a number of organisations, such as very small left-wing groups, but also more influential ones such as Attac, the Occupy movement, or Die Linke (The Left) in Germany. Sarah Wagenknecht, representing the Marxist wing within The Left, has argued for these demands over the last few years since she got involved in the regulatory reform debates within the European Parliament and gained some wider public attention in the German discourse. The party programme, adopted in 2011, very much follows her earlier line by calling for 'a banking

88 K Marx and F Engels, Manifesto of the Communist Party (1848) <www.marxists.org/archive/marx/works/1848/ communist-manifesto/index.htm>.

89 V I Lenin, 'The Tasks of the Proletariat in the Present Revolution [aka The April Theses]' (1917 <www.marxists.org/archive/lenin/works/1917/apr/04.htm>.

90 V I Lenin, 'The Impending Catastrophe and How to Combat It' (1917) <www.marxists.org/archive/ lenin/works/1917/ichtci/index.htm>.

91 Ibid. 
system with three pillars: savings banks, cooperative banks and large state banks'. 'A functioning financial sector', the programme continues, 'is a public good, so providing it is a public task.' Banks should be mandated to follow 'social and ecological guidelines' and 'to serve the public weal'. In their governance structures they should moreover incorporate 'guaranteed strong codetermination rights as a corrective to management decisions'. Direct citizens' involvement is proposed with regard to 'the development of municipal services'. Public property of the large banks would assure a 'new economic management' and political priority setting. 'Private banks must . . . be nationalized, subjected to democratic control and made to serve the public weal.' The 'public service mission' must be protected by 'strict regulation'. Investment banking must 'be phased out, it must be forbidden for banks to trade in securities for their own account and to speculate in derivatives, as well as to transact any business outside of their own balance and to have any dealings with companies or persons legally registered in tax havens'. Hedge funds and private equity firms should be banned, capital controls reintroduced and various speculative products banned. ${ }^{92}$

All these proposals are not elaborated in any detail with regard to how 'democratic control' or 'workers' control' should work. However, they raise a question that addresses how practices and activities of finance could be brought into line with a wider public interest. They also take into account that financial stability and many activities banks should provide are public and no longer private. It goes without saying that these proposals have not been taken up by any regulators and that they are marginalised views. But, even from a less radical perspective, there are a number of lessons to be drawn from the nationalisations of the crisis years so far, especially with regard to repeated bailouts. Regulators need to be better prepared for nationalisations and must take much stricter requirements into account before they nationalise a bank. This is a debate that is still largely underdeveloped in the current turmoil and preoccupation with crisis management. A complete socialisation of banks and democratic control, however, would definitely require a revolution or an enormous shock such as a break-up of the Eurozone or another massive aftershock; this could not possibly come into existence via gradual institutional reforms.

\subsection{RECOVERY AND RESOLUTION PLANS}

More prominently on the agenda are demands for the orderly resolution of failing institutions. The regulatory reforms adopted or discussed so far have focused on unwinding 'SIFIs and 'globally systemically important banks' (G-SIBs) via so-called living wills, funeral plans and orderly resolution systems. This policy is a reaction to the lesson that the current system with all the interconnectedness and complexity makes it nearly impossible to let failing banks go bankrupt. In short, it tries to end the TBTF and 'too-interconnected-tofail' problem and the survival of highly undercapitalised 'zombie banks'. The core ideas were agreed on at G20 level, the Financial Stability Board provided guidance, and the policy has now to be implemented. The US adopted this approach in the Dodd-Frank Act (Title I, s 165(d)) and has already started implementation. A first group of megabanks had to submit their funeral plans by mid-2012, with a second group following by mid-2013.

The EU is lagging behind and plans have been delayed due to the crisis at member-state level as well as in Brussels. The European Commission presented a proposal in June $2012^{93}$ that is now being debated.

92 Die Linke, Programme of the Die Linke Party (Die Linke 2011).

93 A Bank Recovery and Resolution Directive (COM(2012) 280/3) together with a first impact assessment (SWD(2012) 166 final). 
There are several serious problems with these approaches. Firstly, they require frequently updated public and confidential reports with the latter only being seen by the regulatory authorities. The overall soundness and effectiveness rests with the quality of the confidential reports and the willingness of regulatory authorities to enforce a strict policy. Given the historic experiences with regulatory capture and foreseeable problems of strict implementation in good times, the current designs are not very promising. Insiders from the US have argued that the initial experience is rather disappointing and that the banks' living wills were not of a high standard. This might change via gradual institutional reforms and learning processes over time. Secondly, there are serious doubts about how living wills would actually work in a crisis and whether this might increase capital concentration. ${ }^{94}$ Thirdly, there are doubts if the idea works at all as long as all the banks are so interconnected. ${ }^{95}$ Yet there is also the problem of US regulators being able to shut down smaller institutions but not the larger megabanks because Dodd-Frank only applies in the US and does not cover cross-border operations. ${ }^{96}$ In short, there are still many problems to be solved with regard to the orderly resolution of failing banks.

\section{Conclusion}

This paper discussed why structural reforms of finance became so prominent with the global financial crisis and why structures need to be changed. The adopted regulatory reforms with a direct effect on financial structures that have been analysed have introduced significant changes, which, however, will not transform the current system of financialisation. They have, of course, to be seen in the context of the wider reforms that are taking place, especially indirect regulation affecting the structures of finance or product regulations that were beyond the focus of this paper. What can be learned from direct regulation is that overly complex rules were created with the purpose of generating flaws and loopholes that do not undermine the dominance of finance created by overly complex and interconnected sectoral structures. Foremost, these rules made the divergence between the US, with the adoption of the Volcker Rule, and the UK and the EU, with their proposals for ring-fencing systems, less significant by ensuring no threat to competitive advantages in the corresponding domestic systems. It is still too early to anticipate the overall effects the reforms will generate on regulatory competition in the long run and in particular on the financial centres' futures. What is already clear, however, is that the complexity of the regulatory reforms allows for a number of problematic aspects and trends to continue. The policy window for a radical system overhaul has not been used so far. Complexity and uncertainties as well as highly technical legal debates and existing regulatory governance practices give moderate reform proposals an advantage and leave radical left proposals marginalised. The contemporary practice of the better law-making approach with stakeholder consultations and impact assessments made it easy to adopt only proposals reflecting dominant powers and interests. The framing of such processes as well as the difficulties in calculating long-term effects of reform proposals and the lack of corresponding studies were identified as essential in several debates. A radical overhaul of financialisation is difficult to achieve without more public pressure and stronger countervailing powers. Aftershocks or the next level of the crisis could easily bring more radical proposals onto the agenda. These more radical regulatory ideas are not all new but

94 J Silver-Greenberg and N Schwartz, “Living Wills” for Too-Big-to-Fail Banks Are Released', New York Times (New York, 4 July 2012).

95 J Eisinger, 'Banking Regulator Calls for End of “Too Big To Fail”, New York Times (New York, 28 March 2012).

96 S Johnson, 'The Myth of Resolution Authority', New York Times Economix (New York, 31 March 2011). 
build on longer traditions as shown. They have been adopted and modified to new situations over time. Nevertheless, they are mostly still underdeveloped and lack clear transformative strategies that could make them reality. Some ideas like narrow banking or limited purpose banking are more of a minor expert discourse, while nationalisation seems to be a more natural response driven by different motivations in specific situations that could quickly spread. Most influential on actual reforms were, however, warnings against over-regulation and ideas about structures mainly created by market developments. Given the strong pressures from industry in the overall climate of crisis management and recovery, it is a success that the adopted structural reforms are at least making the overall system more preventive compared to the pre-crisis system. Whether gradual institutional reforms will improve institutional arrangements and whether strict implementation and enforcement can be ensured over time is still uncertain and will need close attention by regulators and researchers. 
